\title{
PENGARUH THRUST DEDUCTION FACTOR DAN WAKE FRACTION TERHADAP EFISIENSI PROPULSI AKIBAT PERUBAHAN SARAT AIR KAPAL
}

\section{The Effect of Thrust Deduction Factor and Wake Fraction Toward Propulsion Efficiency Due To Changes in the Draught of Ship}

\author{
Muhammad Sawal Baital $^{1, a}$, Kusnindar Priohutomo² ${ }^{2}$ Jatmika Prajayastanda $^{1}$, Solichin Djazuli Sa'id ${ }^{1}$ \\ ${ }^{1}$ Sekolah Vokasi Universitas Diponegoro, Jl. Prof. Sudarto, Tembalang, Semarang, Indonesia \\ ${ }^{2}$ Balai Teknologi Hidrodinamika, Badan Pengkajian dan Penerapan Teknologi, Jl. Hidrodinamika BPPT, Surabaya, Indonesia \\ e-mail: asawalbaital@lecturer.undip.ac.id
}

Diterima: 24 Maret 2021; Direvisi: 12 Juli 2021; Disetujui: 14 Juli 2021

\begin{abstract}
Abstrak
Penelitian ini untuk memprediksi efisiensi propulsi akibat perubahan sarat kapal menggunakan data series dan pendekatan secara teoritis. Sebuah kapal rescue boat dengan bentuk lambung hard chine yang memiliki tiga susunan propeller digunakan untuk studi dan menguji pengaruh thrust deduction factor dan wake fraction karena perubahan draft kapal serta kaitannya dengan efisiensi propulsi dengan mengamati interaksi antara lambung dan propeller berdasarkan pengujian open water yang diberikan oleh Wageningen Data Series dengan mengabaikan analisis kavitasi. Penelitian ini dikerjakan dengan menggunakan analisis hidrodinamika untuk kapal dengan lambung planning dan menggunakan perpotongan antara kurva karakteristik gaya gorong dengan pengujian open water untuk propeller fixed pitch. Hasil penelitian ini menunjukkan bahwa perubahan draft kapal sangat mempengaruhi perubahan nilai thrust deduction factor dan wake fraction yang merupakan salah satu faktor penyebab perubahan nilai efisiensi propulsi 1 - 5\%.
\end{abstract}

Kata kunci: wake fraction; thrust deduction; propulsi; efisiensi

\begin{abstract}
This study is to investigate propulsion efficiency due to changes in draught of ship using data series and theoretical approach. A hard chain rescue boat with triplet screw was used for the study and to examine the effect of thrust deduction factor and wake fraction due to changes in draught of ship and its relevance to propulsion efficiency by observing hull and propeller interaction based on openwater test by Wageningen Data Series with cavitations analysis has been neglected. The study is done using hydrodynamics analysis for planning hull and using intersection between thrust characteristic curves with openwater test data series for fixed pitch propeller. The result indicated that the changes in ship draught are very influential on the changes in thrust deduction factor and wake fraction value which is one of the contributing factor to change the propulsion efficiency value 1 - 5\%.
\end{abstract}

Keywords: wake fraction; thrust deduction; propulsion; efficiency 
(Muhammad Sawal Baital, Kusnindar Priohutomo, Jatmika Prajayastanda dan Solichin Djazuli Sa'id)

\section{PENDAHULUAN}

Propeller merupakan device yang digunakan untuk menghasilkan thrust atau gaya dorong berdasarkan kombinasi putaran (rpm), yang di transmisikan dari mesin utama melalui shaft atau poros (Molland, 2008). Thrust yang dihasilkan harus mampu mengatasi total resistance yang bekerja pada kapal saat kapal bergerak pada kecepatan tertentu (Carlton, 2012). Karena propeller merupakan sebuah device pada kapal yang mampu meningkatkan akselerasi fluida yang melewatinya, maka perbedaan susunan propeller akan berdampak pada perbedaan efisiensi propeller yang berdampak pula pada perbedaan kecepatan kapal (Fr) pada daya mesin dan rpm yang sama (Vesting, 2015). Hal ini menghasilkan sebuah interaksi antara lambung kapal dan propeller. Bentuk lambung berdampak terhadap efisiensi propeller dan efisiensi propeller mempengaruhi desain propeller (Molland, et al., 2017). Sehingga diperlukan analisis yang dapat digunakan untuk mendapatkan kesesuaian tersebut.

Performa propeller kapal selalu meningkat seiring berjalannya waktu dengan adanya prosedur desain dan analisis yang lebih akurat, baik melalui metode numerik atau metode pengujian eksperimental yang lebih baik pada skala model maupun skala penuh. Meskipun peningkatan signifikan telah dicapai, banyak masalah berbeda yang masih harus dihadapi, dengan tujuan untuk meningkatkan kualitas dari performa propeller (Ridha \& Utama, 2017).

Efisiensi propulsi merupakan salah satu aspek penting dan telah banyak penelitian sebelumnya yang meng-evaluasi-nya. Proses evaluasi ini dilakukan dibanyak aspek salah satunya susunan propeller. Proses evaluasi didasarkan pada tahapan-tahapan tertentu secara berurutan yang disebut dengan powering process stage seperti yang ditunjukkan pada Gambar 1, dimulai dari mengestimasi total gaya hambat yang bekerja pada kapal pada kecepatan tertentu, menentukan karakteristik propeller dan mengestimasi daya mesin utama (Baital, et al., 2020).

Penelitian ini akan membahas bagaimana pengaruh perubahan sarat kapal terhadap nilai thrust deduction factor dan wake fraction serta kaitannya terhadap efisiensi propeller kapal, dalam studi kasus ini yaitu rescue boat yang memiliki susunan propeller triple screw.

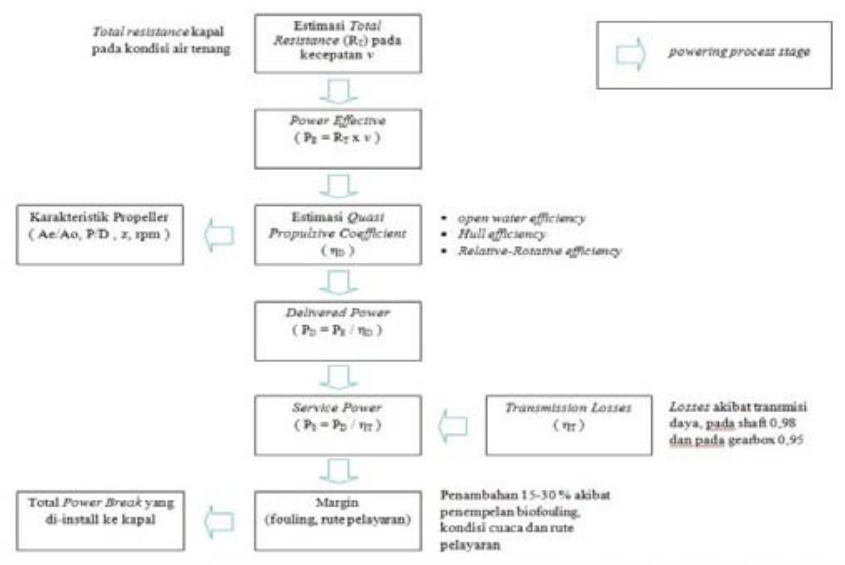

Gambar 1. Powering process stage

Penelitian ini memiliki beberapa hambatan, salah satu diantaranya yaitu nilai thrust deduction factor yang diperoleh dari perbedaan antara thrust propeller itu sendiri dengan gaya hambat kapal tanpa propeller dan nilai wake fraction yang merupakan perbedaan antara kecepatan relatif gerak maju propeller terhadap fluida dengan kecepatan kapal atau kecepatan pengamatan. Dalam menentukan nilai dari thrust deduction factor dan wake fraction, gaya dorong yang dihasilkan propeller yang terpasang di kapal sedapat mungkin sebanding dengan propeller pada kondisi open water (thrust identity) sehingga dapat didefinisikan bahwa thrust deduction factor merupakan perbandingan antara selisih gaya dorong dan total gaya hambat dengan gaya dorong.

Perubahan sarat kapal akan diikuti dengan perubahan luas permukaan basah, panjang garis air dan juga form factor sehingga berakibat pada penurunan peforma kapal serta efisiensi propulsi (Alexandrina, 2015).

\section{Kapal Penyelamat (Rescue Boat)}

Kapal penyelamat atau rescue boat yang termasuk ke dalam jenis kapal high speed craft (HSC). Kapal ini harus mampu beroperasi dengan baik pada kecepatan tinggi disemua kondisi cuaca (Molland, 2008). 


\section{Sistem Propulsi}

Sebuah kapal yang beroperasi di laut harus memiliki kemampuan untuk mempertahankan kecepatan sesuai dengan rancangannya, sehingga kapal harus memiliki rancangan sistem propulsi yang dapat mengatasi seluruh gaya hambat yang bekerja pada kapal (Renilson, 2015). Sistem propulsi terdiri dari sistem penggerak utama, sistem transmisi dan propulsor. Ketiga sistem ini merupakan satu kesatuan yang tidak dapat dianalisis secara terpisah saat merancang kapal (Pena, et al., 2019). Dampak yang ditimbulkan karena kesalahan dalam perencanaan sistem propulsi antara lain berkurangnya nilai ekonomis kapal, tidak tercapainya kecepatan yang direncanakan serta konsumsi bahan bakar yang tidak efisien (Andersson, et al., 2018).

\section{METODE}

Analisis efisiensi propeller dilakukan dengan menggunakan metode Hull-Propeller Interaction, dengan mencari kesesuaian antara bentuk lambung kapal dan propeller yang di-install ke kapal berdasarkan nilai quasi propulsive coefficient (QPC) menggunakan persamaan (1).

$$
Q P C=\eta_{o} \times \eta_{r r} \times \eta_{\text {hull }}
$$

Kesesuaian ini didasarkan pada nilai efisiensi open water terbesar yang didapatkan dari perpotongan antara thrust propeller dan efisiensi open water pada grafik Wageningen B-Series (Kuiper, 1992).

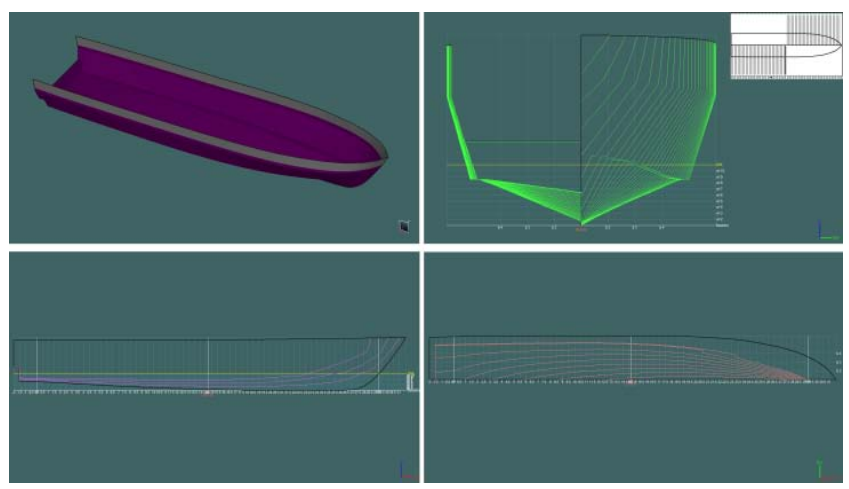

Gambar 2. Rancangan rescue boat

Seluruh tahapan analisis dilakukan pada kapal rescue boat seperti yang ditunjukkan oleh Gambar 2, dengan lambung hard-chine yang memiliki ukuran utama seperti yang ditunjukkan oleh Tabel 1 .

Tabel 1. Dimensi utama kapal

\begin{tabular}{ccc}
\hline Item & Satuan & Nilai \\
\hline LOA & $\mathrm{m}$ & 41,00 \\
\hline LWL & $\mathrm{m}$ & 37,56 \\
\hline BWL & $\mathrm{m}$ & 6,68 \\
\hline H & $\mathrm{m}$ & 3,90 \\
\hline $\mathrm{T}$ & $\mathrm{m}$ & 1,55 \\
\hline Vs & $\mathrm{knot}$ & 29,00 \\
\hline Disp. & ton & 157,70 \\
\hline Vol. & $\mathrm{m}^{3}$ & 153,83 \\
\hline WSA & $\mathrm{m}^{2}$ & 246,89 \\
\hline
\end{tabular}

Analisis dilakukan pada beberapa kondisi sarat yang disesuaikan dengan kondisi operasional kapal yaitu 100\% (sarat penuh), 95\%, 90\%, 85\%, 80\% dan 75\%. Analisis dilakukan pada kecepatan dinas kapal, dengan membalik tahapan pada powering process stage seperti yang ditunjukkan oleh Gambar 3. Dalam prosesnya, daya mesin (power break, $\mathrm{P}_{\mathrm{B}}$ ) yang terpasang di kapal dikonversi menjadi daya efektif (power effective, $\mathrm{P}_{\mathrm{E}}$ ) menggunakan persamaan (2).

$$
P_{B}=\left(P_{E} / \eta_{D}\right) \times\left(1 / \eta_{T}\right)+\text { margin }
$$

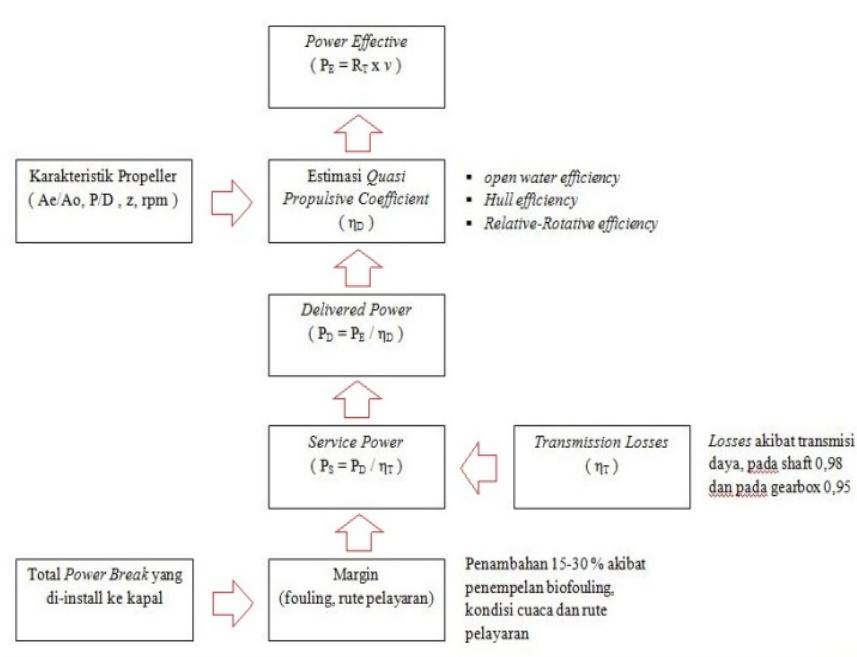

Gambar 3. Tahapan konversi $\mathrm{P}_{\mathrm{B}}$ menjadi $\mathrm{P}_{\mathrm{E}}$ 
Pengaruh Thrust Deduction Factor dan Wake Fraction terhadap Efisiensi Propulsi Akibat Perubahan Sarat Air Kapal

(Muhammad Sawal Baital, Kusnindar Priohutomo, Jatmika Prajayastanda dan Solichin Djazuli Sa'id)

Tabel 2. Hasil analisis hambatan total

\begin{tabular}{|c|c|c|c|c|c|c|}
\hline \multirow{2}{*}{ Froude Number } & \multicolumn{6}{|c|}{ Hambatan Total ( kN) } \\
\hline & $75 \%$ & $80 \%$ & $85 \%$ & $90 \%$ & $95 \%$ & $100 \%$ \\
\hline 0,670 & 71,7 & 72,1 & 83,3 & 84,3 & 101,4 & 105,0 \\
\hline 0,697 & 76,0 & 79,5 & 91,0 & 97,9 & 106,3 & 109,5 \\
\hline 0,724 & 80,3 & 84,3 & 95,7 & 102,7 & 111,3 & 114,1 \\
\hline 0,750 & 84,8 & 90,7 & 100,4 & 107,6 & 116,3 & 118,8 \\
\hline 0,777 & 89,2 & 95,1 & 105,2 & 112,5 & 121,4 & 123,5 \\
\hline 0,804 & 93,8 & 100,2 & 110,0 & 117,4 & 126,4 & 128,3 \\
\hline 0,831 & 98,3 & 106,5 & 114,8 & 122,3 & 131,5 & 133,1 \\
\hline 0,858 & 102,9 & 110,7 & 119,7 & 127,3 & 136,6 & 137,8 \\
\hline
\end{tabular}

\section{HASIL DAN PEMBAHASAN}

Kapal yang digunakan dalam penelitian ini adalah rescue boat dengan panjang keseluruhan $41 \mathrm{~m}$ dengan bentuk lambung hard-chine planning. Kapal ini menggunakan fixed pitch propeller dengan tiga susunan propeller atau triple screw. Kapal ini memiliki tiga mesin utama dengan daya masing-masing $1400 \mathrm{HP}$ dengan 2100 rpm dan rasio gearbox 1 : 1,5. Karena kondisi operasional, kapal ini mengalami perubahan sarat dengan kondisi sarat minimum yaitu $75 \% \mathrm{~T}$ sedangkan sarat maksimum adalah $100 \% \mathrm{~T}$.

\section{Karakteristik Propeller}

Propeller yang digunakan adalah Wageningen $B$-Series dengan jenis fixed pitch berdiameter 1,1 m dengan 5 bilah atau 5 daun propeller. Propeller ini memiliki rasio luas bilah Ae/Ao sebesar 0,76 atau B5-76. Karakteristik propeller berdasarkan data Wageningen open water test yang digunakan kapal rescue boat ini pada kondisi 100\% T.

\section{Estimasi Hambatan Total Kapal}

Hambatan kapal dianalisis pada kondisi sarat 100\%, 95\%, 90\%, 85\%, 80\% dan 75\%. Analisis dilakukan menggunakan analisis karakteristik hidrodinamis kapal high speed craft dengan bentuk lambung planning (Yousefi, et al., 2013). Estimasi hambatan total kapal untuk setiap kondisi dihitung dengan menggunakan persamaan (3) dan (4), sedangkan hasil analisis hambatan total kapal pada setiap kondisi ditunjukkan oleh Tabel 2.

$$
\begin{aligned}
& R_{S}=\frac{1}{2} \rho v^{2} \Delta \lambda b^{2} C_{f} \\
& R_{T}=\Delta \tan \tau \frac{0.5 \rho v^{2} \lambda b^{2} C_{f}}{\cos \tau x \cos \beta}
\end{aligned}
$$

\section{Thrust Deduction Factor dan Wake Fraction}

Nilai thrust deduction factor dan wake fraction ditentukan berdasarkan gaya dorong yang dihasilkan propeller yang terpasang di kapal sedapat mungkin sebanding dengan propeller pada kondisi open water. Nilai keduanya dapat ditentukan dengan menggunakan persamaan (5) dan (6). Perubahan nilai thrust deduction factor dan wake fraction dapat dilihat pada Tabel 3.

$$
\begin{aligned}
& t=1-\frac{R}{T_{b}}=1-\frac{0.5 \rho S V^{2} C_{T S}}{\rho n^{2} D^{4} K_{T B}} \\
& w=1-\frac{V_{o}}{V_{S}}=1-\frac{n D J_{o}}{n D J_{b}}=1-\frac{J_{o}}{J_{b}}
\end{aligned}
$$


Tabel 3. Efisiensi propeller pada kondisi 75\% T

\begin{tabular}{ccc}
\hline Sarat & $\mathrm{t}$ & $\mathrm{w}$ \\
\hline $75 \%$ & 0,17 & 0,13 \\
\hline $80 \%$ & 0,17 & 0,13 \\
\hline $85 \%$ & 0,18 & 0,14 \\
\hline $90 \%$ & 0,19 & 0,15 \\
\hline $95 \%$ & 0,19 & 0,15 \\
\hline $100 \%$ & 0,21 & 0,17 \\
\hline
\end{tabular}

\section{Analisis Kesesuaian Hambatan Propeller}

Gaya dorong (thrust) yang dihasilkan oleh propeller harus mampu melawan total gaya hambat yang bekerja pada kapal. Dengan asumsi bahwa thrust propeller minimal memiliki besaran yang sama dengan thrust kapal pada kondisi massa jenis air $(\rho)$, koefisien hambatan total $\left(\mathrm{C}_{\mathrm{T}}\right)$ dan luas bidang basah (S) lambung kapal adalah konstan $(\alpha)$ atau berada pada kondisi yang sangat ideal (Pecoraro, et al., 2013), maka kesesuaian antara thrust kapal dan thrust propeller dapat dihitung dengan pendekatan seperti yang ditunjukkan oleh persamaan (7) dan (8).

$$
\begin{aligned}
& T_{\text {ship }}=T_{\text {prop }} \\
& \frac{\alpha \times v_{A}{ }^{2}}{(1-t)(1-w)^{2}}=K_{T} \times \rho \times n^{2} \times D^{4}
\end{aligned}
$$

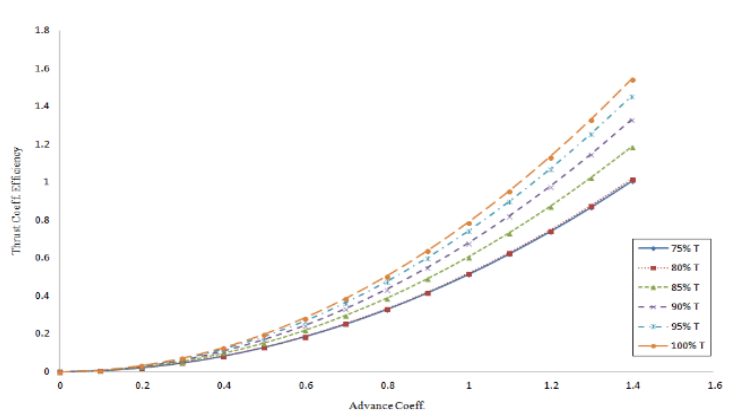

Gambar 4. Karakteristik thrust kapal

Berdasarkan persamaan (7) dan (8), maka diperoleh kurva karakteristik thrust kapal untuk setiap kondisi seperti yang ditunjukkan oleh Gambar 4

Kurva yang ditunjukkan pada Gambar 4 menunjukkan perubahan nilai efisiensi koefisien thrust terhadap perubahan nilai koefisien advance. Kurva karakteristik thrust kapal ini kemudian digambarkan ke kurva open water test (Wageningen $B$-Series) yang sesuai dengan karakteristik propeller yakni B5-76, sehingga diperoleh kesesuaian antara hambatan dan karakteristik propeller yang digunakan pada kapal untuk setiap kondisi.

\section{Kondisi 75\% Sarat}

Gambar 5 merupakan hasil analisis sistem propulsi pada kondisi sarat $1,16 \mathrm{~m}$ atau $75 \%$ sarat kapal.

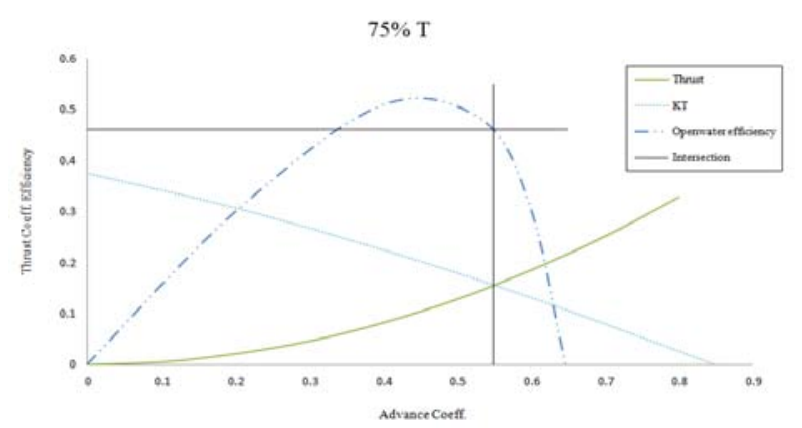

Gambar 5. Kurva interaksi hambatan dan propeller pada kondisi 75\% T

Gambar 5 menunjukkan efisiensi open water test pada pitch ratio (P/D) 0,80 dengan koefisien advance (J) 0,550 sebesar 0,460.

Tabel 4. Efisiensi propeller pada kondisi 75\% T

\begin{tabular}{cccccc}
\hline$\eta_{\mathrm{o}}$ & $\eta_{\mathrm{r}}$ & $\eta_{\mathrm{h}}$ & $\eta p$ & $\mathrm{t}$ & $\mathrm{w}$ \\
\hline 0,460 & 0,960 & 0,943 & 0,416 & 0,17 & 0,13 \\
\hline
\end{tabular}

Berdasarkan Tabel 4, karakteristik propeller B5-76 pada P/D dan J masing-masing 0,80 dan 0,550 memiliki efisiensi propulsi sebesar $41,6 \%$ tetapi tidak memiliki kesesuaian dengan rasio gearbox dan putaran mesin pada maximum continuous service. Pada kondisi ini, thrust deduction factor dan wake fraction masing-masing sebesar 0,17 dan 0,13.

\section{Kondisi 80\% Sarat}

Gambar 6 merupakan hasil analisis sistem propulsi pada kondisi sarat 1,24 m atau $80 \%$ sarat. 
Pengaruh Thrust Deduction Factor dan Wake Fraction terhadap Efisiensi Propulsi Akibat Perubahan Sarat Air Kapal

(Muhammad Sawal Baital, Kusnindar Priohutomo, Jatmika Prajayastanda dan Solichin Djazuli Sa'id)

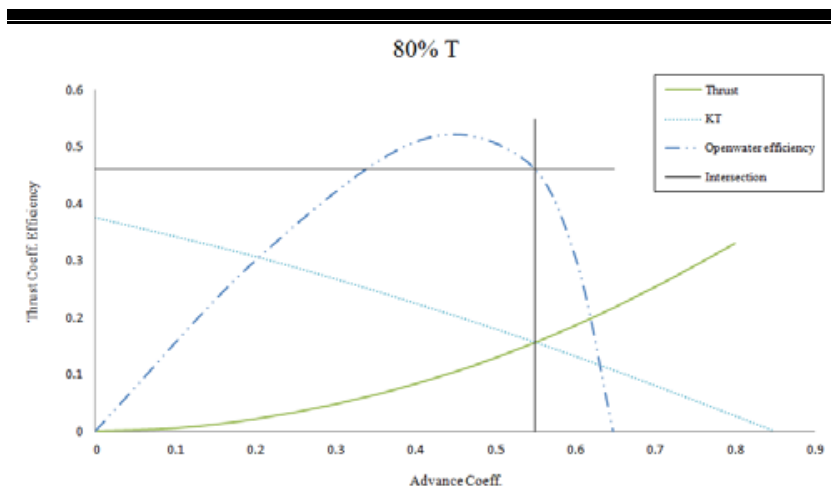

Gambar 6. Kurva interaksi hambatan dan propeller pada kondisi 80\% T

Gambar 6 menunjukkan efisiensi open water test pada pitch ratio (P/D) 0,80 dengan koefisien advance (J) 0,550 sebesar 46,0\%.

Tabel 5. Efisiensi propeller pada kondisi 80\% T

\begin{tabular}{cccccc}
\hline$\eta_{\mathrm{o}}$ & $\eta_{\mathrm{r}}$ & $\eta_{\mathrm{h}}$ & $\eta \mathrm{p}$ & $\mathrm{t}$ & $\mathrm{w}$ \\
\hline 0,460 & 0,960 & 0,944 & 0,417 & 0,17 & 0,13 \\
\hline
\end{tabular}

Berdasarkan Tabel 5, karakteristik propeller B5-76 pada P/D dan J masing-masing 0,80 dan 0,550 memiliki efisiensi propulsi sebesar $41,7 \%$ tetapi tidak memiliki kesesuaian dengan rasio gearbox dan putaran mesin pada maximum continuous service. Pada kondisi ini, thrust deduction factor dan wake fraction masing-masing sebesar 0,17 dan 0,13.

\section{Kondisi 85\% Sarat}

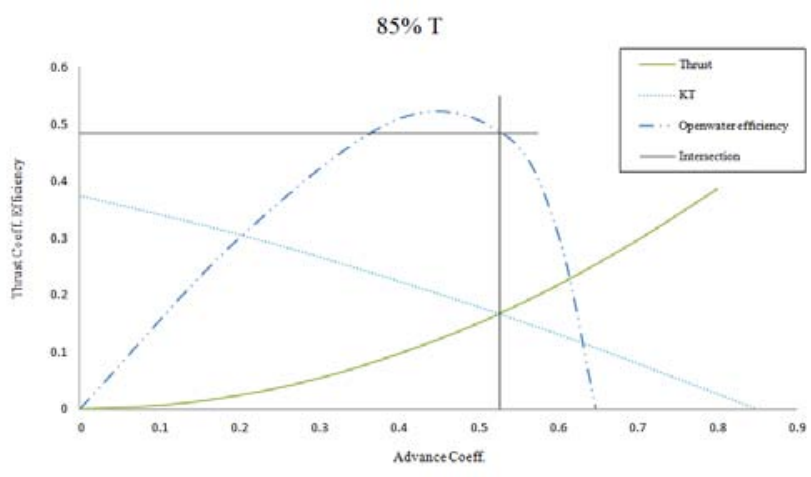

Gambar 7. Kurva interaksi hambatan dan propeller pada kondisi $85 \% \mathrm{~T}$

Gambar 7 merupakan hasil analisis sistem propulsi pada kondisi sarat 1,32 $\mathrm{m}$ atau $85 \%$ sarat.
Gambar 7 menunjukkan efisiensi open water test pada pitch ratio (P/D) 0,80 dengan koefisien advance (J) 0,527 sebesar 48,5\%.

Tabel 6. Efisiensi propeller pada kondisi 85\% T

\begin{tabular}{cccccc}
\hline$\eta_{\mathrm{o}}$ & $\eta_{\mathrm{r}}$ & $\eta_{\mathrm{h}}$ & $\eta \mathrm{p}$ & $\mathrm{t}$ & $\mathrm{w}$ \\
\hline 0,485 & 0,960 & 0,944 & 0,440 & 0,18 & 0,14 \\
\hline
\end{tabular}

Berdasarkan Tabel 6, karakteristik propeller B5-76 pada P/D dan J masing-masing 0,80 dan 0,527 memiliki efisiensi propulsi sebesar $44,0 \%$ tetapi tidak memiliki kesesuaian dengan rasio gearbox dan putaran mesin pada maximum continuous service. Pada kondisi ini, thrust deduction factor dan wake fraction masing-masing sebesar 0,18 dan 0,14 .

\section{Kondisi 90\% Sarat}

Gambar 8 merupakan hasil analisis sistem propulsi pada kondisi sarat 1,39 $\mathrm{m}$ atau $90 \%$ sarat kapal.

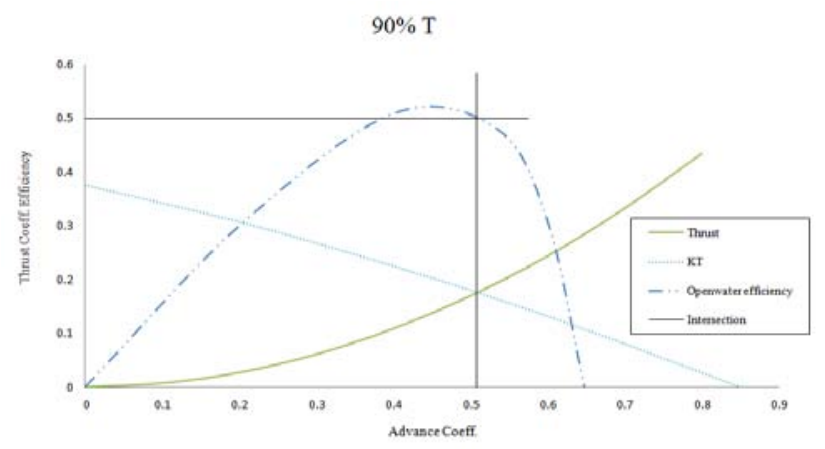

Gambar 8. Kurva interaksi hambatan dan propeller pada kondisi $90 \% \mathrm{~T}$

Gambar 8 menunjukkan efisiensi open water test pada pitch ratio (P/D) 0,80 dengan koefisien advance (J) 0,508 sebesar 50,0\%.

Tabel 7. Efisiensi propeller pada kondisi 90\% T

\begin{tabular}{cccccc}
\hline$\eta_{\mathrm{o}}$ & $\eta_{\mathrm{r}}$ & $\eta_{\mathrm{h}}$ & $\eta \mathrm{p}$ & $\mathrm{t}$ & $\mathrm{w}$ \\
\hline 0,500 & 0,960 & 0,945 & 0,454 & 0,19 & 0,15 \\
\hline
\end{tabular}

Berdasarkan Tabel 7, karakteristik propeller B5-76 pada P/D dan J masing-masing 0,80 dan 0,508 memiliki efisiensi propulsi sebesar 45,4\% 
tetapi tidak memiliki kesesuaian dengan rasio gearbox dan putaran mesin pada maximum continuous service. Pada kondisi ini, thrust deduction factor dan wake fraction masing-masing sebesar 0,19 dan 0,15.

\section{Kondisi 95\% Sarat}

Gambar 9 merupakan hasil analisis sistem propulsi pada kondisi sarat 1,47 $\mathrm{m}$ atau $95 \%$ sarat.

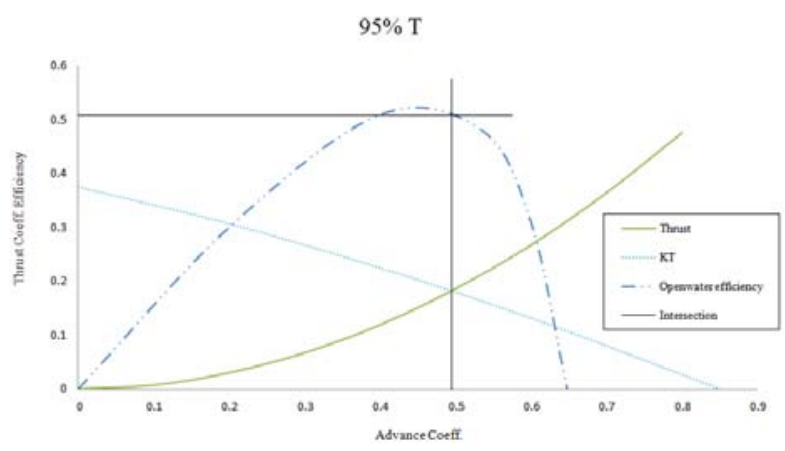

Gambar 9. Kurva interaksi hambatan dan propeller pada kondisi 95\% T

Gambar 9 menunjukkan efisiensi open water test pada pitch ratio (P/D) 0,80 dengan koefisien advance (J) 0,495 sebesar 50,8\%.

Tabel 8. Efisiensi propeller pada kondisi 95\% T

\begin{tabular}{cccccc}
\hline$\eta_{\mathrm{o}}$ & $\eta_{\mathrm{r}}$ & $\eta_{\mathrm{h}}$ & $\eta p$ & $\mathrm{t}$ & $\mathrm{w}$ \\
\hline 0,508 & 0,960 & 0,947 & 0,462 & 0,19 & 0,15 \\
\hline
\end{tabular}

Berdasarkan Tabel 8, karakteristik propeller B5-76 pada P/D dan J masing-masing 0,80 dan 0,508 memiliki efisiensi propulsi sebesar 46,2\% tetapi tidak memiliki kesesuaian dengan rasio gearbox dan putaran mesin pada maximum continuous service. Pada kondisi ini, thrust deduction factor dan wake fraction masing-masing sebesar 0,19 dan 0,15.

\section{Kondisi $100 \%$ Sarat}

Gambar 10 merupakan hasil analisis sistem propulsi pada saat proses perancangan hingga pembangunan kapal yang menjadi dasar pemilihan jenis propeller yang digunakan pada rescue boat ini.

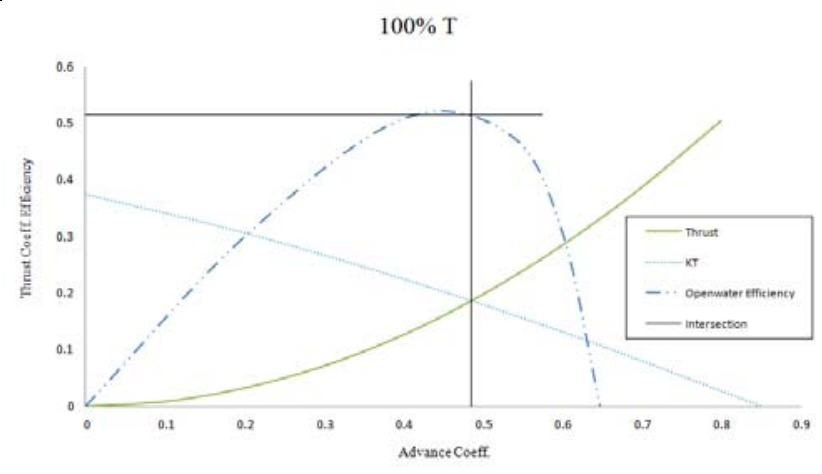

Gambar 10. Kurva interaksi hambatan dan propeller pada kondisi $100 \% \mathrm{~T}$

Gambar 10 menunjukkan efisiensi open water test pada pitch ratio (P/D) 0,80 dengan koefisien advance (J) 0,485 sebesar 51,5\%.

Tabel 9. Efisiensi propeller pada kondisi 100\% T

\begin{tabular}{cccccc}
\hline$\eta_{\mathrm{o}}$ & $\eta_{\mathrm{r}}$ & $\eta_{\mathrm{h}}$ & $\eta \mathrm{p}$ & $\mathrm{t}$ & $\mathrm{w}$ \\
\hline 0,515 & 0,960 & 0,948 & 0,469 & 0,21 & 0,17 \\
\hline
\end{tabular}

Berdasarkan Tabel 9 karakteristik propeller B5-76 pada P/D dan J masing-masing 0,80 dan 0,485 memiliki efisiensi propulsi sebesar $46,9 \%$ dan memiliki kesesuaian dengan rasio gearbox dan putaran mesin pada maximum continuous service. Pada kondisi ini, thrust deduction factor dan wake fraction masing-masing sebesar 0,21 dan 0,17.

\section{Analisis Penyesuaian P/D}

Berdasarkan kurva karakteristik thrust kapal seperti yang ditunjukkan pada Gambar 4, untuk mempertahankan nilai efisiensi propulsi pada setiap kondisi maka perlu dilakukan penyesuaian pitch ratio (P/D).

\section{Kondisi 75\% Sarat}

Gambar 11 merupakan hasil analisis sistem propulsi pada kondisi sarat $1,16 \mathrm{~m}$ atau $75 \%$ sarat kapal. Gambar tersebut menunjukkan efisiensi open water test pada pitch ratio (P/D) 0,68 dengan koefisien advance (J) 0,485 sebesar 51,5\%. Berdasarkan analisis tersebut, karakteristik propeller B5-76 pada P/D dan J masing-masing 0,68 dan 0,485 memiliki efisiensi propulsi sebesar 
Pengaruh Thrust Deduction Factor dan Wake Fraction terhadap Efisiensi Propulsi Akibat Perubahan Sarat Air Kapal

(Muhammad Sawal Baital, Kusnindar Priohutomo, Jatmika Prajayastanda dan Solichin Djazuli Sa'id)

51,5\% dan memiliki kesesuaian dengan rasio gearbox dan putaran mesin pada maximum continuous service.

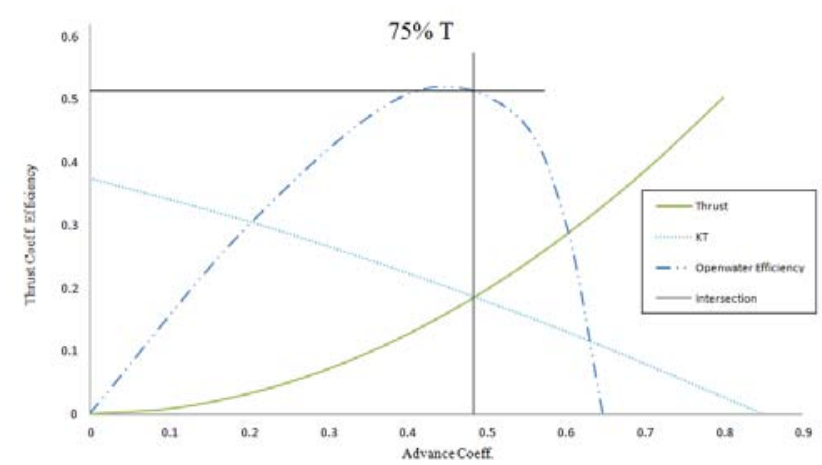

Gambar 11. Kurva interaksi hambatan dan propeller pada kondisi 75\% T dengan penyesuaian P/D

\section{Kondisi 80\% Sarat}

Gambar 12 merupakan hasil analisis sistem propulsi pada kondisi sarat $1,24 \mathrm{~m}$ atau $80 \%$ sarat.

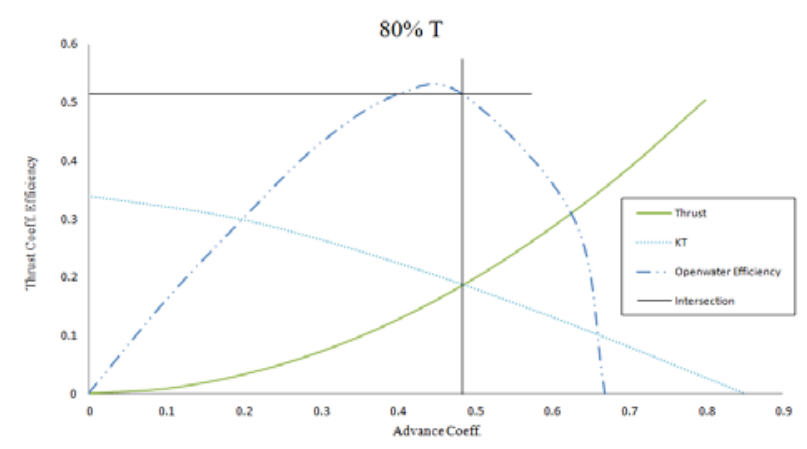

Gambar 12. kurva interaksi hambatan dan propeller pada kondisi 80\% T dengan penyesuaian P/D

Gambar 12 menunjukkan efisiensi open water test pada pitch ratio (P/D) 0,66 dengan koefisien advance (J) 0,485 sebesar 51,5\%. Berdasarkan analisis tersebut, karakteristik propeller B5-76 pada P/D dan J masing-masing 0,68 dan 0,485 memiliki efisiensi propulsi sebesar $51,5 \%$ dan memiliki kesesuaian dengan rasio gearbox dan putaran mesin pada maximum continuous service.

\section{Kondisi 85\% Sarat}

Gambar 13 merupakan hasil analisis sistem propulsi pada kondisi sarat 1,32 $\mathrm{m}$ atau $85 \%$ sarat.

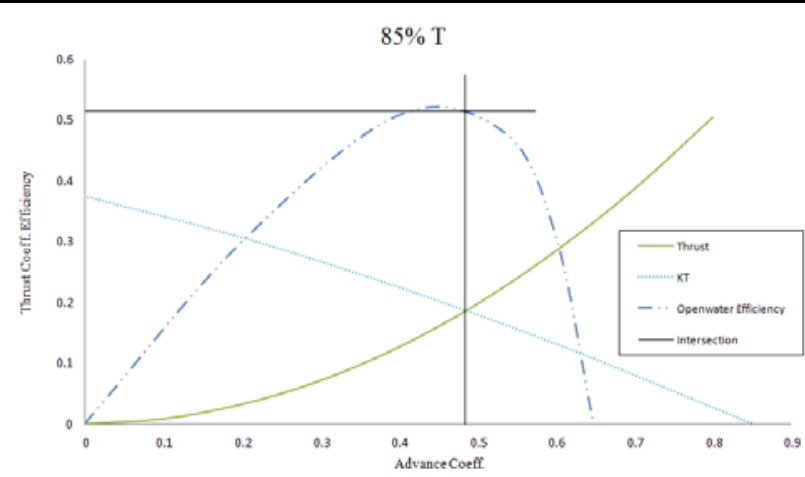

Gambar 13. Kurva interaksi hambatan dan propeller pada kondisi 85\% T dengan penyesuaian P/D

Gambar 13 menunjukkan efisiensi open water test pada pitch ratio (P/D) 0,70 dengan koefisien advance (J) 0,485 sebesar 51,5\%. Berdasarkan analisis tersebut, karakteristik propeller B5-76 pada P/D dan J masing-masing 0,70 dan 0,485 memiliki efisiensi propulsi sebesar $51,5 \%$ dan memiliki kesesuaian dengan rasio gearbox dan putaran mesin pada maximum continuous service.

\section{Kondisi 90\% Sarat}

Gambar 14 merupakan hasil analisis sistem propulsi pada kondisi sarat 1,39 m atau $90 \%$ sarat kapal.

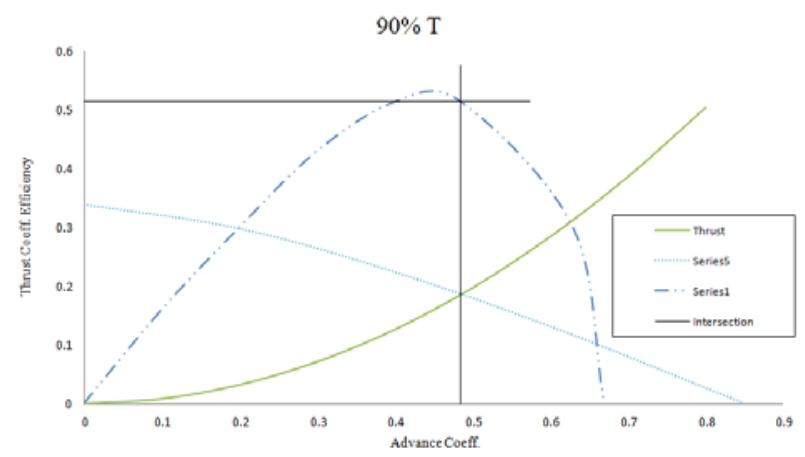

Gambar 14. Kurva interaksi hambatan dan propeller pada kondisi 90\% T

Gambar 14 menunjukkan efisiensi open water test pada pitch ratio (P/D) 0,71 dengan koefisien advance (J) 0,485 sebesar 51,5\%. Berdasarkan analisis tersebut, karakteristik propeller B5-76 pada P/D dan J masing-masing 0,71 dan 0,485 memiliki efisiensi propulsi sebesar 
51,5\% dan memiliki kesesuaian dengan rasio gearbox dan putaran mesin pada maximum continuous service.

\section{Kondisi 95\% Sarat}

Gambar 15 merupakan hasil analisis sistem propulsi pada kondisi sarat 1,47 $\mathrm{m}$ atau $95 \%$ sarat.

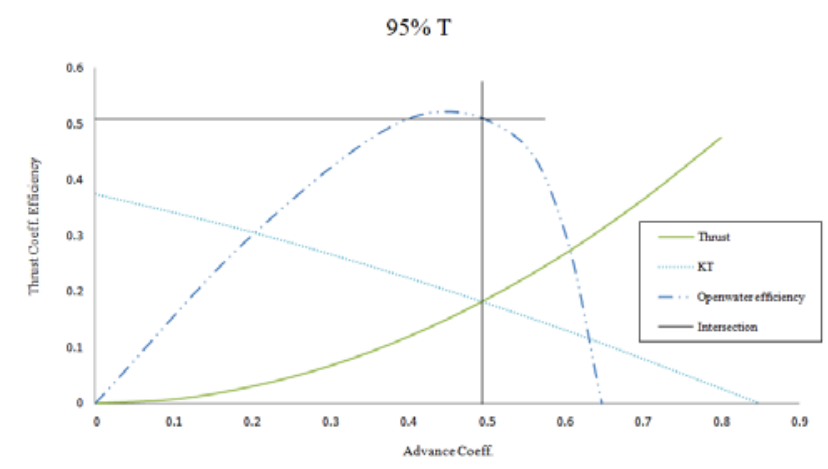

Gambar 15. Kurva interaksi hambatan dan propeller pada kondisi 95\% T

Gambar 15 menunjukkan efisiensi openwater test pada pitch rasio (P/D) 0,78 dengan koefisien advance (J) 0,485 sebesar 51,5\%. Berdasarkan analisis tersebut, karakteristik propeller B5-76 pada $\mathrm{P} / \mathrm{D}$ dan $\mathrm{J}$ masing-masing 0,78 dan 0,485 memiliki efisiensi propulsi sebesar $51,5 \%$ dan memiliki kesesuaian dengan rasio gearbox dan putaran mesin pada maximum continuous service.

\section{KESIMPULAN}

Berdasarkan hasil analisis, perubahan sarat kapal sangat mempengaruhi karakteristik gaya hambat dan gaya dorong kapal (thrust). Perubahan karakteristik gaya hambat mempengaruhi interaksi hambatan dan propeller karena kurva karakteristik gaya hambat ini digambarkan ke dalam kurva open water test untuk mendapatkan karakteristik propeller yang sesuai dengan bentuk lambung dan mesin utama.

Perubahan sarat kapal ini juga dapat mengakibatkan terjadinya perubahan terhadap nilai thrust deduction factor dan wake fraction karena keduanya sangat dipengaruhi oleh bentuk lambung kapal yang tercelup di air. Thrust deduction factor sendiri sangat dipengaruhi oleh perubahan luas bidang basah kapal dan koefisien hambatan total kapal. Walaupun perubahan nilai thrust deduction factor dan wake fraction sangat kecil, namun perubahan ini sangat mempengaruhi nilai efisiensi lambung kapal sehingga berdampak langsung terhadap perubahan nilai quasi propulsive coefficient (QPC) atau nilai efisiensi propulsi.

Selain itu, perubahan sarat kapal sangat berpengaruh terhadap perubahan nilai thrust deduction factor dan wake fraction yang menjadi salah satu faktor penyebab perubahan nilai efisiensi propulsi $1 \%$ hingga $5 \%$. Sehingga dapat disimpulkan bahwa untuk mempertahankan efisiensi propulsi pada setiap kondisi operasional dibutuhkan penyesuaian pitch ratio (P/D). Dalam contoh kasus ini maka langkah yang dapat diambil yaitu penggunaan propeller berjenis controlable pitch.

\section{UCAPAN TERIMA KASIH}

Terima kasih kepada Balai Teknologi Hidrodinamika yang telah memberikan open water test propeller B-Series, serta kepada Badan Nasional Pencarian dan Pertolongan yang telah memberikan data kapal RB-40 untuk digunakan dalam penelitian ini.

\section{DAFTAR PUSTAKA}

Alexandrina, V. (2015). Study of the Effect of Trim on Ship Powering Performance. Scientific Proceedings XXIII International Scientific-Technical Conference "Trans \& Motauto '15", 151-154. Varna Bulgaria, Scientific-Technical Union of Mechanical Engineering.

Andersson, J. Eslamdoost, A., Patrao, A. C., Hyensjo, M., Bensow, R. E. (2018). Energy Balance Analysis of a Propeller in Open Water. Ocean Engineering, Vol. 158, pp. 162-170.

Baital, M. S., Putranto, A. B. \& Waluyo, B. S. (2020). Analisa Engine Propeller Matching (EPM) pada Kapal Rescue Boat karena 
Pengaruh Thrust Deduction Factor dan Wake Fraction terhadap Efisiensi Propulsi Akibat Perubahan Sarat Air Kapal

(Muhammad Sawal Baital, Kusnindar Priohutomo, Jatmika Prajayastanda dan Solichin Djazuli Sa'id)

Perubahan Tahap Powering Process. Gema Teknologi, Vol. 21(1), pp. 49-55.

Carlton, J. (2012). Marine Propellers and Propulsion, Marine Propellers and Propulsion. 3th Edition. Oxford: Butterworth-Heinemann.

Kuiper, G. (1992). The Wageningen Propeller Series. Wageningen: MARIN Publication.

Molland, A. F. (2008). The Maritime Engineering Reference Book: A Guide to Ship Design, Construction and Operation. Oxford: Butterworth-Heinemann.

Molland, A. F., Turnock, S. R. \& Hudson, D. A. (2017). Ship Resistance and Propulsion. 2nd Edition. Cambridge: Cambridge University Press.

Pecoraro, A., Felice, F. D., Felli, M., Salvatore, F., \& Viviani, M. (2013). Propeller-Hull Interaction in a Single-Screw Vessel. Third International Symposium on Marine Propulsors (pp. 185-192). Australian Maritime College, University of Tasmania.

Pena, B., Pavic, E. M. \& Ponkratov, D. (2019). Achieving a High Accuracy Numerical
Simulations of The Flow Around a Full Scale Ship. Proceedings of the ASME 2019 38th International Conference on Ocean, Offshore and Arctic Engineering OMAE2019, 1-10. Glasgow, American Society of Mechanical Engineers (ASME).

Renilson, M. (2015). Propulsion. In: Submarine Hydrodynamics. SpringerBriefs in Applied Sciences and Technology. Hillerød: Springer, Cham.

Ridha, N. M. \& Utama, I. K. A. P. (2017). Studi Kasus: Analisis Peningkatan Efisiensi Thrust Akibat Penerapan Energy Saving Device pada Kapal Tanker Pertamina (Persero) 40000 LTDW dengan Ansys Fluent Menggunakan Metode Moving Mesh. Jurnal Teknik ITS, Vol. 6(1), pp. G47-G52.

Vesting, F. (2015). Marine Propeller Optimisation Strategy and Algorithm Development. Disertasi. Chalmers University of Technology.

Yousefi, R., Shafaghat, R. \& Shakeri, M. (2013). Hydrodynamic Analysis Techniques for High-Speed Planing Hulls. Applied Ocean Research, Vol. 42, pp. 105-113. 